\title{
Pengembangan bahan ajar fisika pada materi pengukuran berbasis kearifan lokal Kalimantan Barat
}

\author{
Matsun \\ Program Studi Pendidikan Fisika, IKIP PGRI Pontianak, Indonesia \\ Surat-e: matsunzaidan@gmail.com \\ Ira Nofita Sari \\ Program Studi Pendidikan Fisika, IKIP PGRI Pontianak, Indonesia \\ Surat-e: iranofitasari87@gmail.com

\section{Boisandi} \\ Program Studi Pendidikan Fisika, IKIP PGRI Pontianak, Indonesia \\ Surat-e: bsandi2012@gmail.com
}

\begin{abstract}
Abstrak. Penelitian yang dilakukan didasari oleh belum adanya buku ajar fisika SMA kelas $\mathrm{X}$ pada materi pengukuran yang mengaitkan antara kearifan lokal Kalimantan Barat dengan konsep fisika. Oleh karena itu, penelitian ini bertujuan untuk mengembangkan buku ajar fisika pada materi pengukuran berbasis kearifan lokal Kalimantan Barat. Secara khusus penelitian ini bertujuan untuk mengetahui kelayakan buku ajar fisika pada materi pengukuran berbasis kearifan lokal Kalimantan Barat. Metode penelitian yang digunakan yaitu metode penelitian dan pengembangan (R\&D) dengan menggunakan model 4-D (FourD Models) yang terdiri dari empat tahap, yaitu tahap pendefinisian (define), tahap perancangan (design), tahap pengembangan (develop), dan tahap pendeseminasian (disseminate). Intrumen yang digunakan yaitu instrument non test berupa angket validasi menggunakan skala likert dengan rentang skor 1-4. Berdasarkan hasil analisis data diketahui bahwa buku ajar fisika pada materi pengukuran berbasis kearifan lokal Kalimantan Barat memiliki hasil validasi untuk ahli materi dengan skor rata-rata $82,5 \%$ dan validasi ahli media dengan skor rata-rata 82,25\%. Buku ajar fisika pada materi pengukuran berbasis kearifan lokal Kalimantan Barat dengan kriteria sangat baik menurut ahli materi dan ahli media sehingga buku ajar yang dikembangkan dapat digunakan dalam pembelajaran fisika..
\end{abstract}

Kata kunci: pengembangan, bahan ajar, pengukuran, kearifan lokal

\begin{abstract}
The research conducted was based on the absence of class X high school physics textbook on measurement material that linked West Kalimantan local wisdom with the concept of physics. Therefore, this study aims to develop physics textbooks on measurement materials based on the local wisdom of West Kalimantan. In particular, this study aims to determine the feasibility of physics textbooks on measurement materials based on the local wisdom of West Kalimantan. The research method used is the research and development (R\&D) method using the 4-D model (Four-D Models), which consists of four stages, namely the defining stage, the design stage, the development stage, and the dissemination stage. The instrument used is a non-test instrument in the form of a validation questionnaire using a Likert scale with a score range of 1-4. Based on the results of data analysis, it is known that physics textbooks on measurement materials based on local wisdom of West Kalimantan have validation results for material experts with an average score of $82.5 \%$ and validation of media experts with an average score of $82.25 \%$. Physics textbooks on measurement material based on local wisdom of West Kalimantan with very good criteria according to material experts and media experts so that the textbooks developed can be used in physics learning.
\end{abstract}

Keywords: development, teaching materials, measurement, local wisdom 


\section{Pendahuluan}

Dunia pendidikan pada masa revolusi industry 4.0 mengalami perkembangan yang sangat pesat. Pendidikan merupakan media dalam mengembangkan sumber daya manusia serta sebagai wahana untuk mengembangkan potensi siswa. Proses pendidikan berjalan secara efektif jika memiliki kualitas yang baik serta siswa memiliki pengalaaman yang bermakna dalam pembelajaran dikelas. Proses pendidikan yang bermakna harus di sesuai dengan kondisi siswa dalam belajar fisika.

Fisika merupakan cabang dari ilmu pengetahuan alam (IPA) yang terdiri atas beberapa konsep dasar terkait dengan fenomena-fenomena yang terjadi di kehidupan sehari-hari [1]. Proses pembelajaran fisika dapat menjadi pembelajaran yang bermakna bagi peserta didik ketika materi fisika dikaitkan dengan kearifan lokal yang ada di daerah setempat. Karena siswa merasakan langsung dan mudah dirasakan langsung oleh siswa.

Kearifan lokal merupakan suatu pandangan hidup, ilmu pengetahuan dan berbagai strategi kehidupan yang terwujud dalam aktivitas masyarakat lokal untuk menjawab berbagai masalah pemenuhan kebutuhan anggota masyarakat tersebut [2]. Kearifan lokal juga didefinisikan sebagai bentuk kekayaan setempat atau suatu daerah berupa kepercayaan, pengetahuan, norma, kebudayaan, adat istiadat, wawasan, dan lain sebagainya yangdiwariskan dan dipertahankan sehingga menjadi sebuah identitas dan pedoman untuk mengajarkan cara bertindak secara tepat dalam menjalani kehidupan [3].

Untuk menghubungkan antara kearifan lokal dengan materi pelajaran fisika dalam dunia pendidikan maka diperlukan suatu bahan ajar yang dapat menjadi jembatan.salah satunya adalah bahan ajar berupa modul. Modul [4] merupakan media cetak yang sengaja dirancang secara sistematis dan bertujuan supaya dapat digunakan oleh peserta didik dalam kegiatan pembelajaran. Bahan ajar dibuat menyesuaikan dengan karakteristik siswa. Hal ini dilakukan agar dengan adanya bahan ajar tersebut siswa dapat dengan mudah memahami dan belajar secara mandiri. Dengan adanya bahan ajar yang memadai, peserta didik dapat belajar dan mendiskusikan materi ajar sebelum pembelajaran dimulai. Di samping itu, bahan ajar juga mampu memberikan tuntunan yang jelas mengenai kompetensiyang ingin dicapai oleh peserta didik [5].

Bahan ajar memiliki fungsi strategis bagi proses belajar mengajar. Bahan ajar dapat membantu siswa dan guru dalam kegiatan pembelajaran, sehingga guru tidak terlalu banyak menyajikan materi. Disamping itu, bahan ajar dapat menggantikan sebagian peran guru dan mendukung pembelajaran individual. Hal ini akan memberi dampak positif bagi guru, karena sebagian waktunya dapat dicurahkan untuk membimbing belajar siswa. Dampak positifnya adalah dapat mengurangi ketergantungan pada pendidik dan membiasakan belajar mandiri [6].

Bahan ajar yang dikembangkan yaitu buku ajar fisika SMA kelas X pada materi pengukuran yang memuat konten kearifan lokal Kalimantan Barat. Kalimantan Barat merupakan daerah 3T, sehingga kearifan lokal harus dimuat dalam buku ajar agar siswa memiliki rasa cinta tanah air. Sebagai ilustrasi pembelajaran tentang alat ukur dimana masyarakat Kalimantan Barat mengenal istilah alat ukur dan takaran yang sering digunakan oleh suku Melayu dan Dayak Kalimantan Barat. Suku Dayak dan Melayu menggunakan ukuran gantang, cuntang, timpurung, baleq, cupak, genggam, dan borong dalam melakukan pengukuran. Gantang dibuat dari kayu ulin atau kayu keras lainnya sebagai alat ukur takaran, bentuk gantang itu bulat panjang, biasanya digunakan untuk menakar padi atau beras, satu gantang kurang lebih seberat $2,5 \mathrm{~kg}$. Satu cuntang sama dengan 1 liter kadang penggunaan kata cuntang bisa digantikan dengan liter, timpurung merupakan ukuran yang menggunakan tempurung kelapa, satu timpurung sebesar $1 / 4 \mathrm{~kg}$. Baleq merupakan satu kaleng minyak tanah/ minyak makan jaman dahulu. Cupak dipakai untuk menakar beras yang akan dimasak oleh setiap rumah tangga sehari-hari. Satu cupak kurang lebih $1 / 4 \mathrm{~kg}$. Genggam ukuran segenggam orang dewasa, biasanya untuk mengukur jumlah beras yang diberikan untuk memberi makan ayam. Borong merupakan ukuran untuk menyatakan suatu luasan areal tanah persawahan atau perladangan, satu borong biasanya sebesar 10 depa persegi, atau $1 / 6$ hektar atau 1666,66 $\mathrm{m}^{2}$. Buku ajar yang dikembangkan juga memuat nilainilai karakter siswa. Dengan menggunakan bahan ajar fisika pada materi pengukuran, siswa akan memiliki nilai-nilai karakter yang sesuai dengan kearifan lokal Kalimantan Barat dan siap untuk menghadapi era revolusi industri 4.0 .

Kearifan lokal merupakan suatu bentuk kecerdasan yang dihasilkan dalam kehidupan bermasyarakat pemilik dari kebudayaan tersebut. Sehingga, kearifan lokal adalah suatu pemikiran tentang hidup yang dilandasi budi baik yang dijadikan pandangan hidup berupa aktivitas dalam masyarakat lokal untuk memenuhi kebutuhan hidupnya [7]. Kearifan lokal selalu bersumber dari hidup masyarakat melalui 
pengalaman yang yang dialaminya [8]. Pendidikan berintergrasi kearifan lokal adalah pendidikan yang mengajarkan peserta didik untuk mengenal sesuatu yang konkret dalam kehidupannya bermasyarakat [9].

Kearifan lokal yang menjadi tradisi di daerah akan lebih cepar terserap oleh siswa untuk berpikir, bertindak, dan bersikap sesuai dengan dengan tuntutan adat dan kebudayaan daerah setempat. Alternatif pembelajaran karakter yang malah mengimpor dari luar sehingga kurang menyentuh aspek kejiwaan siswa yang berada pada wilayah yang ditargetkan. Karakter-karakter tersebut kurang bisa mengilmahami siswa karena bedanya budaya dan karakter setempat, maka dengan kearifan local merupakan jawaban atas banyak pertanyaan tentang bagaimana mangatasi perilaku siswa dalam proses pembelajaran. Salah satu inovasi yang dapat dilakukan guru adalah membuat bahan ajar yang dapat meningkatkan motivasi peserta didik seperti menghadirkan kehidupan nyata atau sesuatu yang ada di lingkungan ke dalam pembelajaran [10]. Kekayaan atau potensi lokal daerah dapat dijadikan tema dalam mengembangkan bahan ajar adalah potensi lokal yang ada di sekitar siswa. Seperti yang diungkapkan [11] bahwa potensi lokal merupakan pembelajaran nyata yang mampu melayani masyarakat dalam memecahkan masalah lingkungan. Bahan ajar yang dikembangkan dengan tema potensi lokal dapat dilakukan dengan berbagai cara, salah satunya yaitu merancang pembelajaran berdasarkan potensi lokal sebagai sumber belajar yang dikemas dalam bentuk buku ajar.

Adanya keterkaitan antara materi pengukuran dengan kearifan lokal Kalimantan Barat dapat mendukung pembelaajran di kelas. Agar pembelajaran di kelas dapat berjalan secara efektif diperlukanlah bahan ajar fisika pada materi pengukuran. Pada pengembangan bahan ajar fisika pada materi pengukuran berbasis kearifan lokal diharapkan dapat menigkatkan hasil belajar siswa. Hal ini sesuai dengan penelitian yang dilakukan oleh [12] bahwa pengembangan modul fisika berintegrasi kearifan lokal Berdasarkan hasil pengembangan dan uji coba, diperoleh simpulan bahwa Modul Fisika berintegrasi kearifan lokal Hulu Sungai Selatan layak untuk digunakan dalam proses pembelajaran. Hal ini didukung oleh validitas isi modul yang berkategori valid dan validasi tampilan berkategori sangat valid, kepraktisan modul berkategori sangat praktis, dan efektivitas modul berkategori tinggi.

\section{Metode Penelitian}

Penelitian ini bertujuan untuk mengetahui kelayakan bahan ajar fisika pada materi pengukuran berbasis kearifan lokal Kalimantan Barat. Metode penelitian yang digunakan yaitu metode penelitian dan pengembangan (R\&D) dengan menggunakan model 4-D (Four-D Models) yang terdiri dari empat tahap, yaitu tahap pendefinisian (define), tahap perancangan (design), tahap pengembangan (develop), dan tahap pendeseminasian (disseminate). Tahap pengembangan yang dilakukan pada penelitian ini dilakukan hingga tahap develop. Subjek dalam penelitian ini adalah bahan ajar fisika pada materi pengukuran berbasis kearifan lokal Kalimantan Barat.

Intrumen yang digunakan yaitu instrumen non test berupa angket validasi menggunakan skala likert dengan rentang skor 1-4. Angket yang digunakan dalam penelitian ini diberikan kepada ahli materi dan ahli media yang masing-masing bejumlah dua orang dengan isi pernyataan yang sesuai dengan kebutuhan. Selanjutnya hasil angket dianalisis dengan perhitungan persentase dan diinterpretasikan berdasarkan kategori menggunakan Tabel 1 [13].

Tabel 1. Rentang Kategori Nilai Hasil Validasi Ahli Materi dan Ahli Media

\begin{tabular}{ccl}
\hline No. & Skor $(\boldsymbol{\%})$ & \multicolumn{1}{c}{ Kriteria } \\
\hline 1 & $76-100$ & Sangat Baik \\
2 & $51-75$ & Baik \\
3 & $26-50$ & Cukup Baik \\
4 & $0-25$ & Kurang Baik \\
\hline
\end{tabular}

\section{Hasil Penelitian dan Pembahasan}

Hasil penelitian ini berupa kelayakan bahan ajar fisika pada materi pengukuran berbasis kearifan lokal Kalimantan Barat yang sangat baik digunakan dalam pembelajaran fisika di sekolah. Hasil dan pembahasan dalam penelitian ini dijabarkan berdasarkan tahapan dari 4-D. 


\section{Pendefinisian (Define)}

Tujuan dari tahap ini adalah menetapkan dan mendefinisikan syarat-syarat pengembangan buku ajar. Dalam menentukan syarat-syarat pembelajaran diawali dengan analisis tujuan dari pokok bahasan. Analisis ujung depan memiliki tujuan untuk mengetahui masalah pokok yang sedang dihadapi pembelajran fisika pada materi pengukuran yang membutuhakan adanya pengembagan bahan ajar berbasis kearifan lokal Kalimantan Barat. Analisis berikutnya adalah analisis siswa. Analisis ini dilakukan untuk mengetahui kemampuan kognitif dan latar belakang budaya serta lingkungan. Selanjutnya analisis konsep yang mengacu pada materi pengukuran menggunakan Kurikulum 13 Revisi yang merujuk pada kompetensi inti dan kompetensi dasar, sehingga diperoleh tujuan pembelajaran.

Langkah awal yang dilakukan dalam mengembangkan bahan ajar adalah menentukan tujuan pembelajaran yang akan dicapai dan permasalahan pembelajaran dianalisis melalui situasi pembelajaran yang sedang terjadi. Adapun yang menjadi tujuan pada materi pengukuran yaitu siswa dapat: 1) membuat daftar (tabel) nama besaran, alat ukur, cara mengukur dan satuan yang digunakan di daerah Kalimantan Barat; 2) daftar (tabel) nama besaran, alat ukur, cara mengukur dan satuan yang digunakan secara baku; 3) mengetahui cara menggunakan alat ukur, membaca skala dan cara menuliskan hasil pengukuran baku pada beberapa benda.

Permasalahan pembelajaran yang sedang terjadi di Kalimantan Barat yang berhasil dianalisis antara lain, kebutuhan siswa akan konsep konkrit fisika yang bersifat kontekstual. Artinya konsep-konsep fisika yang disampaikan merupakan konsep nyata yang berhubungan dengan kehidupan siswa yang salah satunya dapat dikemas dengan konten kearifan lokal. Banyak konsep pengukuran yang dapat dibentuk melalui budaya lokal siswa. Misalnya alat ukur yang sering digunakan suku Melayu dan Dayak yaitu gantang, timpurang, cuntang, genggam, borong yang selanjutnya dapat dikonversi ke satuan baku dalam konsep fisika, dimana 1 gantang yaitu $2,5 \mathrm{~kg}, 1$ timpurung yaitu $1 / 4 \mathrm{~kg}$, dan sebagainya. Permasalahan berikutnya yaitu belum ada bahan ajar fisika yang dapat mengakomodir kebutuhan akan bahan ajar fisika materi pengukuran berbasis kearifan lokal Kalimantan Barat.

\section{Perancangan (Design)}

Kegiatan pengembangan bahan ajar pada tahap ini meliputi pembuatan desain litbang yang berkaitan tentang lembar validasi, materi, konten, kearifan lokal yang akan dimuat. Lembar validasi ahli media dan materi yang dibuat merujuk pada indikator pengukuran kelayakan bahan ajar. Untuk validasi materi memuat aspek materi, soal/kuis, kebahasaan dan keterlaksanaan, sedangkan untuk validasi media memuat aspek tampilan buku, pemilihan jenis dan ukuran huruf, kejelasan teks, huruf, rumus, dan gambar, serta keserasian tampilan warna dalam buku. Pada tahap perancangan diperoleh desain produk berupa bahan ajar fisika pada materi pengukuran berbasis kearifan lokal Kalimantan Barat yang terdiri dari desain bagian awal, bagian isi dan bagian akhir. Desain bagian awal meliputi desain sampul, pelengkap bagian awal seperti kata pengantar, daftar isi, dan cara penggunaan bahan ajar. Desain bagian isi meliputi tujuan pembelajaran, materi, dan soal/kuis. Desain bagian akhir meliputi daftar istilah dan daftar pustaka. Pada bagian ini juga memperhatikan pemilihan kata atau kalimat yang disajikan, kemudahan memahami konsep, kesesuaian isi materi dengan kemampuan siswa, keterlibatan kearifan lokal yang digunakan, dan peran buku ajar untuk menambah pengetahuan siswa. Adapun spesifikasi produk yang dikembangkan dalam penelitian ini dapat dilihat pada Tabel 2. Produk berupa Bahan Ajar Fisika pada materi pengukuran berbasis kearifan lokal Kalimantan Barat yang dikembangkan dinyatakan layak digunakan apabila telah memenuhi kategori minimal baik dengan rentang skor $51-75 \%$.

Tabel 2. Spesifikasi Produk berupa Bahan Ajar Fisika pada Materi Pengukuran Berbasis Kearifan Lokal Kalimantan Barat

\begin{tabular}{ll}
\multicolumn{1}{c}{ Aspek } & \multicolumn{1}{c}{ Keterangan } \\
\hline Judul & $\begin{array}{l}\text { Bahan Ajar Fisika pada Materi Pengukuran Berbasis } \\
\text { Kearifan Lokal Kalimantan Barat }\end{array}$ \\
Warna & Kombinasi \\
Font & Calibri \\
Size & 12 \\
Jenis kertas & HVS A4 80 gram \\
Ukuran kertas & $210 \times 197 \mathrm{~mm}$
\end{tabular}




\begin{tabular}{ll}
\hline \multicolumn{1}{c}{ Aspek } & \multicolumn{1}{c}{ Keterangan } \\
\hline Margin & B X T X R X L $=4 \mathrm{~cm} \mathrm{X} \mathrm{3cm} \mathrm{X} \mathrm{4cm} \mathrm{X} \mathrm{3cm}$ \\
Sampul & Tertera judul \\
Bagian awal & Kata pengantar, daftar isi, cara penggunaan bahan ajar \\
Bagian isi & Tujuan pembelajaran, materi, soal/kuis \\
Bagian akhir & Daftar pustaka dan daftar istilah \\
\hline
\end{tabular}

Karakteristik Bahan Ajar Fisika pada Materi Pengukuran Berbasis Kearifan Lokal Kalimantan Barat yang dikembangkan yaitu:

a. Pemetaan tujuan dan indikator pembelajaran, menampilkan tujuan dan indikator pada materi pengukuran sesuai dengan Kurikulum-13 Revisi. Pemetaan ini dibuat agar guru dan siswa mudah memahami alur pembelajaran dan target capaian dalam pembentukan konsep pada materi pengukuran

b. Kegiatan pembelajaran yang terurai secara terpadu yang berbasis kearifan lokal Kalimantan Barat untuk menggambarkan kegiatan pembelajaran.

c. Pengalaman belajar yang bermakna melalui kegiata praktikum untuk membangun sikap dan perilaku positif, pemahaman konsep, keterampilan berpikir saintifik, sikap ilmiah dan keterampilan proses sains yang disesuaikan dengan tujuan dan indikator pembelajaran.

d. Kegiatan diskusi yang beragam dengan contoh-contoh studi kasus dalam kehidupan sehari-hari siswa di suatu daeah. Kegiatan diskusi dapat meningkatkan keterampilan berbahasa, pengembangan sikap saling menghargai, dan kemampuan berpikir sistematis.

e. Soal/kuis untuk memperdalam pemahaman konsep siswa terhadap materi pengukuran.

\section{Pengembangan (Develop)}

Setelah diperoleh desain produk berupa bahan ajar, selanjutnya dilakukan validasi kepada ahli materi dan ahli media. Data hasil pengembangan Bahan Ajar Fisika pada Materi Pengukuran Berbasis Kearifan Lokal Kalimantan Barat Tahap III menurut ahli materi dan ahli media disajikan pada Tabel 3 dan 4.

Tabel 3. Hasil Validasi ahli Materi Bahan Ajar Fisika pada Materi Pengukuran Berbasis Kearifan Lokal Kalimantan Barat

\begin{tabular}{lcc}
\hline \multicolumn{1}{c}{ Aspek } & Skor $(\%)$ & Kriteria \\
\hline Materi & $80 \%$ & Sangat Baik \\
Soal/ Kuis & $82 \%$ & Sangat Baik \\
Kebahasaan & $83 \%$ & Sangat Baik \\
Keterlaksanaan & $85 \%$ & Sangat Baik \\
\hline \multicolumn{1}{c}{ Rata-rata } & $\mathbf{8 2 , 5 \%}$ & Sangat Baik \\
\hline
\end{tabular}

Berdasarkan Tabel 3 diketahui bahwa menurut ahli materi aspek materi, soal/kuis, kebahasaan, dan keterlaksanaan dikategorikan sangat baik karena memiliki rata-rata skor $82.5 \%$. Oleh karena itu dari aspek materi, Bahan Ajar Fisika pada Materi Pengukuran Berbasis Kearifan Lokal Kalimantan Barat dikategorikan sangat baik sehingga dapat digunakan dalam pembelajaran dikelas.

Tabel 4. Hasil Validasi ahli Media Bahan Ajar Fisika pada Media Pengukuran Berbasis Kearifan Lokal Kalimantan Barat

\begin{tabular}{lcc}
\hline \multicolumn{1}{c}{ Aspek } & Skor (\%) & Kriteria \\
\hline Tampilan buku menarik & $83 \%$ & Sangat Baik \\
Pemilihan jenis dan ukuran huruf & $84 \%$ & Sangat Baik \\
Kejelasan teks, huruf, rumus, dan gambar & $80 \%$ & Sangat Baik \\
Keserasian tampilan warna dalam buku & $82 \%$ & Sangat Baik \\
\hline \multicolumn{1}{c}{ Rata-rata } & $\mathbf{8 2 , 2 5 \%}$ & Sangat Baik \\
\hline
\end{tabular}

Berdasarkan Tabel 4 diketahui bahwa menurut ahli media aspek tampilan, pemilihan jenis dan ukuran huruf, kejelasan teks, huruf, rumus dan gambar, serta keserasian tampilan warna dalam buku dikategorikan sangat baik karena memiliki rata-rata skor $82.25 \%$. Oleh karena itu dari aspek media, Bahan Ajar Fisika pada Materi Pengukuran Berbasis Kearifan Lokal Kalimantan Barat dikatakan sangat baik dan dapat digunakan dalam pembelajaran dikelas. 
Berdasarkan tabel 3 dan tabel 4 diatas menunjukan bahwa validasi ahli materi dan media pada bahan ajar layak digunakan di dalam kelas. Hal ini sesuai dengan pendapat [14] yang menyatakn bahwa validitas mengacu pada tingkat kecukupan dan kelayakan terhadap interpretasi yang dibuat berdasarkan penilaian [15]. Suatu bahan ajar dinyatakan valid jika isi bahan ajar sesuai dengan kompetensi target belajar. Validasi bahan ajar menurut [16] merupakan suatu proses yang dilakukan untuk menguji kesesuiaan antara bahan ajar dengan kompetensi yang dijadikan sebagai target belajar.

Bahan ajar layak digunakan karena bahan ajar bahan ajar yang dikembangkan sudah memnuhi keteria dari aspek yang dinilai baik dari segi isi maupun tampilan bahan ajar. Hal ini sesuai dengan [17] untuk segi isi bahan ajar, bahan ajar yang dikembangkan harus dapat meningkatkan motivasi siswa untuk belajar dan juga efektif dalam mencapai kempetensi yang diharapkan.

Pembelajaran dengan mengangkat potensi lokal merupkan pembelajaran yang mengangakat hal nyata di dekat peserta didik. Hal ini sesuai dengan yang diungkapkan [18] bahwa potensi lokal merupakan pembelajaran nyata yang mampu melayani masyarakat dalam memecahkan masalah lingkungan. Beberapa masukan mengenai bahan ajar yang digunakan yaitu mengenai isi matei yang berbasis kearifan lokal sebaiknya disertakan asal daerah atau asal budaya secara detail beserta gambar alat ukur yang dimaksud. Selain itu dietiap latihan soal dan soal/kusi hendaknya diberikan tuntunan jawaban.

\section{Kesimpulan}

Pada penelitian ini telah dihasilkan Bahan Ajar Fisika pada Materi Pengukuran Berbasis Kearifan Lokal Kalimantan Barat. Bahan Ajar Fisika pada Materi Pengukuran Berbasis Kearifan Lokal Kalimantan Barat dikatakan sangat layak dengan persentase $82,5 \%$ oleh ahli materi dan sangat layak dengan persentase 82,25\% oleh ahli media. Oleh karena itu secara keseluruhan diketahui bahwa Bahan Ajar Fisika pada Materi Pengukuran Berbasis Kearifan Lokal Kalimantan Barat dikatakan sangat layak digunakan dalam pembelajaran fisika.

\section{Ucapan Terimakasih}

Ucapan terimakasih kepada Kementerian Riset dan Teknologi / Badan Riset dan Inovasi Nasional Republik Indonesia atas pembiyaan yang telah diberikan.

\section{Kepustakaan}

[1] Kurniawan, B. P., Bektiarso, S., \& Subiki. (2012). Penerapan Model Pembelajaran Children Learning In Science (CLIS) Disertai Penilaian Kinerja Dalam Pembelajaran Fisika Untuk Meningkatkan Aktivitas Belajar dan Hasil Belajar Siswa Kelas VIII-A MTs Nurul Amin Jatiroto. Jurnal Pembelajaran Fisika , 328-333.

[2] Fajarini, U. (2014). Peranan Kearifan Lokal Dalam Pendidikan Karakter. SosioDidaktika , 123-130.

[3] Utari, U., Degeng, I. N., \& Akbar, S. (2016). Pembelajaran Tematik Berbasis Kearifan Lokal Di Sekolah Dasar Dalam Menghadapi Masyarakat Ekonomi ASEAN (MEA). Jurnal Teori dan Praksis Pembelajaran IPS , 39-44.

[4] Prastowo, A. (2015). Panduan Kreatif Membuat Bahan Ajar Inovatif. Yogyakarta: Diva Press.

[5] Riduwan. 2010. Skala Pengukuran Variabel-variabel Penelitian. Bandung: Alfabeta.

[6] Lestari, Ivana. Pengembangan Bahan Ajar IPA Berbasis Komik pada Pokok Bahasan Gerak di SMP. Prosiding Seminar Nasional Pendidikan Fisika 2016, 4(5).

[7] Oktaviana, D., Hartini, S., \& Misbah, M. (2017). Pengembangan modul fisika berintegrasi kearifan lokal membuat minyak lala untuk melatih karakter sanggam. Berkala ilmiah pendidikan fisika, 5(3), 272-285

[8] Makhmudah, N. L., Subiki, S., \& Supeno, S. (2019). Pengembangan Modul Fisika Berbasis Kearifan Lokal Permainan Tradisional Kalimantan Tengah Pada Materi Momentum Dan Impuls. Jurnal Pembelajaran Fisika, $8(3), 181-186$.

[9] Rehmat, A. P., \& Bailey, J. M. (2014). Technology Integration in a Science Classroom: Preservice Teachers' Perceptions. J. Sci. Educ. Technol., 23: 744-755.

[10] Tamimiya, K., \& Suryadarma, I. (2019). Potensi lokal Gunung Ijen untuk pemahaman konsep dan berpikir kreatif pengurangan resiko bencana. Jurnal Inovasi Pendidikan IPA, 5(1), 111-128. 
[11] Juniati, E., \& Sari, W. P. (2016). Integrasi potensi lokal pada pembelajaran sl terhadap pembentukan learner softskill untuk memecahkan permasalahan lingkungan. In Prosiding Symbion (Symposium on Biology Education) (pp. 545-546). Yogyakarta: Universitas Ahmad Dahlan.

[12] Hartati, S., Misbah, M., \& Resy, R (2017). Pengembangan modul fisika berintegrasi kearifan local hulu sungai selatan. Jurnal Inovasi dan Pembelajaran Fisika 4(2), 157-162

[13] Widoyoko, E. P. (2016). Evaluasi Program Pembelajaran. Yogyakarta: Pustaka Belajar.

[14] Wilujeng, I., Prasetyo, Z. K., \& Suryadarma, I. G. P. (2017). Science learning based on local potential: Overview of the nature of science (NoS) achieved. In AIP Conference Proceedings (Vol. 1868, p. 080005). AIP Publishing LLC.

[15] Retnawati, H. (2016). Validitas dan Reliabilitas dan Karakteristik Butir. Yogyakarta: Parama Publishing.

[16] Daryanto. (2013). Menyusun Modul. Yogyakarta: Gava Media.

[17] Asyhar, R. (2012). Kreatif Mengembangkan Media Pembelajaran. Jakarta: Referensi Jakarta.

[18] Firdaus, M., \& Wilujeng, I. (2018). Pengembangan LKPD inkuiri terbimbing untuk meningkatkan keterampilan berpikir kritis dan hasil belajar peserta didik. Jurnal Inovasi Pendidikan IPA, 4(1), 26-40. 